\title{
Use of the shower aspersion combined with the swiss ball as a method of pain relief in the active labor stage
}

\author{
Uso do banho de aspersão associado à bola suíça como método de alívio da dor na fase ativa \\ do trabalho de parto
}

Camila de Albuquerque Silva ${ }^{1}$, Sônia Regina Godinho de Lara ${ }^{1}$

DOI 10.5935/2595-0118.20180032

\section{ABSTRACT}

BACKGROUND AND OBJECTIVES: The pain is an inherent phenomenon in labor and may interfere directly with its physiology. The objective of this study was to correlate the effectiveness of the association of the shower aspersion and the swiss ball as a method of pain relief in active labor stage.

CONTENTS: This is an integrative review. The sample was taken from the LILACS, Scielo, BDENF and Medline databases. Fourteen articles were used, published between 2010 and 2016, in the Portuguese and English language. The results indicate a significant reduction of the pain score when associated with both therapies, in addition to acting effectively in the labor progression.

CONCLUSION: The present review allowed the perception that the association of shower aspersion and swiss ball therapies is more effective than its isolated use, enhancing pain relief when applied in the active phase of labor, improving its progression, reducing the duration and stimulating natural childbirth.

Keywords: Baths, Complementary therapies, Hydrotherapy, Labor pain.

\section{RESUMO}

JUSTIFICATIVA E OBJETIVOS: A dor é um fenômeno inerente ao trabalho de parto, podendo interferir diretamente em sua fisiologia, o presente estudo teve por objetivo correlacionar a eficácia da associação do banho de aspersão e da bola suíça como formas de alívio da dor na fase ativa do trabalho de parto.

CONTEÚDO: Para confecção da pesquisa foi utilizada a revisão integrativa, sendo o levantamento da amostra na literatura realizado por meio das bases de dados: LILACS, Scielo, BDENF e Medline. Foram selecionados 14 artigos nos idiomas português

1. Faculdade Israelita de Ciências e Saúde Albert Einstein, Pós-Graduação em Enfermagem Obstétrica e Ginecológica, São Paulo, SP, Brasil.

Submitted in September 18, 2017.

Accepted for publication in March 05, 2018.

Conflict of interests: none - Sponsoring sources: none.

Correspondence to:

Rua São José, 03 - Jardim Novo Osasco

06142-310 Osasco, SP, Brasil.

E-mail: camiladealbuquerquesilva@gmail.com

(C) Sociedade Brasileira para o Estudo da Dor e inglês do período de 2010 a 2016. Os resultados apontam redução significativa do escore de dor quando associadas ambas terapêuticas, além de atuar de modo efetivo na progressáo do trabalho de parto.

CONCLUSÁO: O presente estudo possibilitou a percepção de que a associação das terapêuticas do banho de aspersão e da bola suíça mostrou-se mais eficaz que seu uso isolado, potencializando o alívio da dor quando aplicadas na fase ativa do trabalho de parto, melhorando a progressão do mesmo, diminuindo sua duração e estimulando o parto normal.

Descritores: Banhos, Dor do parto, Hidroterapia, Terapias complementares.

\section{INTRODUCTION}

Pain during the labor process is the main phenomenon felt by women in labor, and it can be related the several factors, such as biological, financial, cultural and emotional. It is necessary to adopt humanizing measures to care for the parturient holistically, improving the evolution of childbirth and the reduction of adverse events allowing the childbirth process to be a unique event ${ }^{1}$.

One of the most important tasks of the professionals who care for the woman during the pregnancy-puerperal process is to provide quality assistance, where the childbirth process is valued as physiological and performed with the adequate use of the technology, as the use of non-pharmacological methods to relieve the pain ${ }^{2}$.

The non-pharmacological methods for pain relief are techniques that even though require a specific knowledge for its use, they do not require complex equipment for its application ${ }^{3}$.

Such methods provide greater autonomy to the woman, with better pain management, decreasing the pain felt as result of the uterine contractions and allowing the adoption of different positions ${ }^{2}$.

Among the recommended non-pharmacological practices for pain relief is the use of shower and the swiss ball. These techniques can be applied isolated or combined ${ }^{4}$.

The warm water of the shower applied on the back of the pregnant woman considerably reduces the pain sensation, alleviating the back pain considered one of main pain reported by parturients, while the use of the swiss ball stimulates the vertical position, improves the tension allowing the relaxation of the pelvic floor. Both the techniques are applied in the first stage of the labor process 5 . 
In this context, we tried to identify the benefits in using non-pharmacological methods for pain relief, aiming at the reduction of interventionist practices and therefore promoting humanistic assistance to childbirth.

It is important to identify the effectiveness of the shower associated with the swiss ball, due to the increasing need to use non-pharmacological methods that provide greater relief of pain in the active phase of childbirth. We believe that the present study will contribute to a better knowledge of the proposed themes and the benefits of their use as non-pharmacological methods for the relief of pain.

The objective of this study was to correlate the efficacy of the association of the shower with the swiss ball as a way to relieve pain in the active phase of childbirth.

\section{CONTENTS}

To elaborate this study, the following stages have been considered: 1) selection of the theme and definition of the guiding question, 2) search of the sample in the literature and establishment of the inclusion and exclusion criteria, 3) data classification, 4) analysis of the selected contents, 5) interpretation of the collected data, and 6) synthesis and presentation of the results ${ }^{6}$.

After selecting the theme of the use of the shower in association with the swiss ball, the following guiding question was defined: "the association of the shower with the swiss ball increases the relief of pain during the active phase of childbirth"? The survey was conducted using the following database: The Caribbean and Latin American literature in Health Sciences (LILACS), Scientific Electronic Library Online (Scielo), Database on Nursing (BDENF) and Medical Literature Analysis and Retrieval System Online (Medline). The articles selected were published from 2010 to 2016, using the following keywords: "Hydrotherapy," "Shower," "Childbirth pain" and "Complementary therapies," all registered in Health Sciences keywords (DeCS).

The criteria used to include the studies were texts in the Portuguese and English languages, published in full in the last seven years, addressing the topics: shower, swiss ball, and childbirth pain, being excluded all the articles that did not meet one of the criteria described.

The initial search resulted in the selection of 26 articles. Then, the instrument of data collection was elaborated including the database where the article has been selected, the title, the language, the year of publication, the subjects of the research, the type of study, place, theme, and the pain assessment method (in the pertinent studies). After the analysis of the data found, 14 articles that corroborated the themes under discussion were selected.

The data were presented in a descriptive approach that allows the analysis, notation, and characterization of the sample data ${ }^{7}$, and divided into thematic categories to present the results obtained. For the elaboration of the study, all the articles used in the discussion come from the Scielo and Medline database. The articles of the LILACS database were used to support the other items of the review. No article of the BDENF database was selected.
Regarding the methodological approach, the studies included adopted the quantitative approach that uses numerical data and statistical resources and techniques for the analysis ${ }^{7}$.

Table 1. Articles included

\begin{tabular}{|c|c|}
\hline Authors & Types of studies \\
\hline Santana et al. ${ }^{8}$ & $\begin{array}{l}\text { Controlled clinical trial, of the therapeutic in- } \\
\text { tervention type }\end{array}$ \\
\hline Pereira and Ribeiro ${ }^{9}$ & Literature review \\
\hline Benfield et al. ${ }^{10}$ & Quantitative study \\
\hline Reis et al. ${ }^{11}$ & Quantitative and retrospective study \\
\hline Gallo et al. ${ }^{12}$ & Literature review \\
\hline Lee et al. ${ }^{13}$ & Randomized and controlled study \\
\hline Silva et al. ${ }^{14}$ & Descriptive study with a quantitative approach \\
\hline Pereira et al. ${ }^{15}$ & $\begin{array}{l}\text { Quantitative approach, exploratory, descripti- } \\
\text { ve and retrospective study }\end{array}$ \\
\hline Lobo et al. ${ }^{16}$ & $\begin{array}{l}\text { Descriptive study with retrospective data col- } \\
\text { lection }\end{array}$ \\
\hline Gallo et al. ${ }^{17}$ & Randomized and controlled study \\
\hline Araújo et al. ${ }^{18}$ & $\begin{array}{l}\text { Descriptive, experimental study with longitu- } \\
\text { dinal characteristic and quantitative approach. }\end{array}$ \\
\hline Taavoni et al. ${ }^{19}$ & Randomized and controlled study \\
\hline Barbieri et al. ${ }^{20}$ & $\begin{array}{l}\text { Experimental clinical trial or randomized and } \\
\text { blind intervention }\end{array}$ \\
\hline Henrique et al. ${ }^{21}$ & Randomized and controlled clinical trial \\
\hline
\end{tabular}

\section{DISCUSSION}

After the analysis of the studies in search for a response to the proposed problem, three thematic categories were defined to guide the discussion: the use of shower; the use of the swiss ball, and the association of the shower and the swiss ball.

The following discussion was divided into three thematic categories to present better the problem proposed. Each thematic section will include the articles selected for its elaboration.

\section{Use of the shower}

For the elaboration of this category, 6 articles were selected ${ }^{8-13}$. The pain and anxiety experienced by the parturient during childbirth can cause effects considered harmful, as the secretion of catecholamines and cortisol $^{8}$.

Such hormones are released to respond to the stress, leading to the activation of two neurohumoral systems, the hypothalamic-pituitary-adrenal axis responsible for the release of cortisol, and the sympathoadrenal medullary system responsible for the release of catecholamines?

The epinephrine and norepinephrine catecholamines raise during labor without analgesia, causing an increase of the cardiac output and the peripheral vascular resistance, also raising the blood pressure, in addition to the reduction of the uterine blood flow, compromising, in turn, the fetal perfusion ${ }^{8}$.

The hydrotherapy, whether in the form of immersion or shower, is widely used around the world to promote comfort, to reduce anxiety and consequently the pain in childbirth. A study conducted with 11 women in labor, using immersion 
in water at $37^{\circ} \mathrm{C}$ for one hour with the purpose to evaluate the mother's pain and anxiety through hormone doses in the plasma evidenced that the use of the hydrotherapy reduces the levels of oxytocin and vasopressin, decreasing the anxiety and consequently, the pain ${ }^{10}$.

A retrospective quantitative study, conducted in 2015, showed that among the practices to relieve pain, the shower is one of the most used. Using nonpharmacological methods makes it possible to replace the pharmacological analgesia and, consequently, reduce interventionists approaches ${ }^{11}$.

The shower promotes the reduction of the catecholamines secretion, reducing the anxiety and increasing the mother's satisfaction. The warm water provides a muscle relaxation through the peripheral vasodilation, resulting in the redistribution of the blood flow ${ }^{12}$.

The muscle relaxation also increases the elasticity of the vaginal opening. This method is free from adverse effects, of low cost and easy to apply ${ }^{8}$.

To enjoy the benefits of this therapy, the water temperature must be taken in consideration and needs to be between 37 and $38^{\circ} \mathrm{C}$, and the parturient must remain in the bath, for at least 20 minutes, directing the water to the painful regions that, in general, are lumbar or the lower abdomen ${ }^{12}$.

In a randomized controlled study conducted in the city of Taipei in Taiwan they, evaluated the shower therapy with warm water at $37^{\circ} \mathrm{C}$, directing the water spray all over the body or to the lumbar region, in the experimental group. The control group received the standard care. The visual analog scale (VAS) was used to assess pain. They found that after the application of the therapy in the experimental group, there was a significant reduction in pain scores in the active phase of childbirth when compared with the control group ${ }^{13}$.

A controlled clinical trial of the therapeutic intervention type evaluated 34 women in labor, with shower application for 30 minutes when the cervical dilation was $4-5 \mathrm{~cm}$, keeping the water temperature between 37 and $39^{\circ} \mathrm{C}$. The labor was of habitual risk, and one of the inclusion criteria was not to use drugs during the period of the study. The pain was assessed according to the VAS, which is a graduated scale of $100 \mathrm{~mm}$, divided into different levels of pain. Pain intensity was assessed before and after applying the therapy. The study concluded that the shower had a positive and significant result, reducing the level of pain from $80 \mathrm{~mm}$ pre-therapy to $55 \mathrm{~mm}$ post-shower intervention $^{8}$.

\section{Use of the swiss ball}

For the elaboration of this category, 6 articles were selected ${ }^{14-19}$. The adoption of vertical positions associated to movement can minimize the pain felt by the parturient, increasing the effectiveness of the uterine contractions, improving the mother-fetus blood circulation, facilitating the delivery descent, and minimizing the occurrence of the perineal trauma ${ }^{14}$.

The swiss ball is one of the methods that stimulate the mother's movement during childbirth, also providing autonomy in the choice of the positions, allowing the swinging of pelvis and squatting since it is used in the sitting position ${ }^{14,15}$.
The ball is an inflatable rubber object, usually used in physiotherapy to correct the posture and treat neurologic pathologies. It was first used in 1963, when Aquiline Corsani, an Italian plastic manufacturer developed it. It received the name of swiss ball in 1989 when swiss physiotherapists realized its benefits and took the ball to the U.S, also receiving the name of the ball of birth, when some years ago it started to be used in labor ${ }^{16,17}$.

There are several benefits in stimulating the mother's mobility during the childbirth process, as the reduction of the use of drugs, promoting dilation, and reducing labor time, and also providing higher resistance to pain. The swiss ball is considered a recreational object since it mobilizes the parturient's attention leading to relaxation and comfort ${ }^{17}$.

The practice of exercises using the swiss ball allows direct action on the pelvic muscles, mainly on the levator ani, pubococcygeus, and the pelvic fascia. The pelvis movement during the therapy relaxes and stretches the muscles ${ }^{14}$.

During childbirth, the adoption of the supine position compresses the vena cava and the aorta, leading to the hypotension of the mother and consequent fetal suffering. In the supine position, the fetus is parallel to the mother's back, making uterus contractions difficult, whereas, in the vertical position, the gravity acts on the mother's uterus pushing it forward and improving the mother-fetus positioning ${ }^{14}$.

In addition to stimulating vertical positions during childbirth, the swiss ball can also be associated with other therapies, as, for example, the shower ${ }^{17}$.

A study conducted in the Centro de Ensino Unificado of the city of Teresina evaluated the Pilates technique that uses the ball. The study showed improvements in the pelvic circulation, stretching structures, and relief of muscle tensions, improving pain after the practice of the exercises. The researchers think that such phenomenon occurred as a result of the so-called "exercise-induced analgesia” due to adaptative pain control mechanisms that release neurotransmitters, noradrenaline, serotonin, dopamine, and enkephalins. It could also have occurred due to the endorphins influence that promotes the reduction of the anxiety sensation anxiety ${ }^{18}$.

A controlled and randomized study with 60 primiparous women with the purpose to evaluate the use of the swiss ball as pain relief showed a significant reduction in the pain score in the group that received the therapy. The pain intensity was assessed with the VAS. The study showed that even though the use of the ball did not directly interfere with the uterine contractions, or in the duration of the labor, it was effective as a method of relief of pain in the active phase ${ }^{19}$.

A randomized and controlled clinical trial conducted at MATER (Center of Reference of Woman's Health of Ribeirão Preto), evaluated 40 women in labor who did pelvic mobility exercises with the ball for 30 minutes, being the pregnancy of habitual risk and the cervical dilation of $4-5 \mathrm{~cm}$. One of the inclusion criteria was not to use pharmacological methods. The pain was assessed by the numeric categorical scale (NCS), observing a significant reduction in pain, from 7.9 pre-therapy to 5.5 after the use of the ball ${ }^{17}$. 


\section{Association of the shower and the swiss ball}

For the elaboration of this category, 2 articles were selected ${ }^{20,21}$. The mother's cervical dilation can be used as an indicator of pain intensity, guiding the use of relief techniques. The pain is considered mild when the dilation is up to $5 \mathrm{~cm}$, progressing from moderate to intense as the dilation evolves. The pain felt for the woman in labor in the dilation period is related to the stimuli transmitted by the fibers of the pelvic structures, associated to the vagina, the cervix uteri and perineal muscles. The pain is less intense at the beginning of childbirth, starting at T10 and irradiating up to S4 in the expulsive stage of labor when its intensity is increased ${ }^{20}$.

During the shower, the action of the local heat promotes the reallocation of the blood flow in the muscles, providing a sensation of relaxation and well-being. Now, the swiss ball works on the perineal region, reducing the pelvic discomfort and the need for analgesia. The association of warm shower and the swiss ball during the first period of labor shows greater effectiveness in promoting comfort and consequent pain relief ${ }^{21}$.

An experimental, blind and randomized clinical trial was conducted in an intra-hospital normal labor center of the Unified Health System (SUS), in the city of São Paulo. The study evaluated 15 women in labor who received the therapeutical application of the shower with warm water and the perineal exercise with the swiss ball, isolated and combined, using the VAS to assess pain. The shower therapy was applied with the water at $37^{\circ} \mathrm{C}$. The parturient could be seated or standing and the water was directed to the lumbosacral region for 30 minutes. For the swiss ball therapy, a $65 \mathrm{~cm}$ ball was used with the parturient seated on it with legs flexed in a $90^{\circ}$ angle, performing rotation and propulsion movements for 30 minutes. The study showed that when used simultaneously, the shower and the ball therapies significantly reduced the pain score when compared with the isolated use ${ }^{20}$.

In a randomized and controlled clinical trial conducted in two public hospitals of the city of Sáo Paulo, 128 women in labor were evaluated when using the warm shower and perineal exercises with the swiss ball therapy, aiming at to evaluate their influence in childbirth progression. For this, a statistical analysis was performed using the SPSS (Statistical Package for the Social Sciences), comparing the frequency of uterine contractions, fetal heart rate, mother's cervix dilation and fetal descent through the mother's pelvis, evaluating the isolate and combined interventions. For the application of the warm shower, a water spray at $37^{\circ} \mathrm{C}$ was applied on the lumbosacral region for 30 minutes, with the mother standing or seated. The perineal exercises were performed with the swiss ball with the mother sitting on it with her legs flexed, separate knees and feet totally on the floor, making rotation and propulsion movements with the pelvis for 30 minutes. The cervical dilation of the participants was $5 \mathrm{~cm}$ since the use of the shower therapy with less dilation is associated with a greater need of pharmacological methods for analgesia. The study showed that the association of the methods effectively changed the labor progression, reducing the duration from $255.05 \mathrm{~min}$. when the shower was applied isolated, and from $288.41 \mathrm{~min}$. when the ball was used isolated, to $216.85 \mathrm{~min}$. with the combined interventions, also leading to a higher incidence of normal labor when compared to the isolated use of therapies ${ }^{21}$.

\section{CONCLUSION}

The present study provided the perception that the association of the shower and swiss ball therapies showed to be more effective than its isolated use, improving pain relief when applied in the active phase of childbirth, improving its progression, reducing its duration and stimulating the normal labor. It is important to highlight that there are still some gaps in this issue due to the small number of existing scientific studies regarding this subject matter.

\section{REFERENCES}

1. Santana LS, Gallo RB, Ferreira CH, Quintana SM, Marcolin AC. Localizaçáo da dor no início da fase ativa do trabalho de parto. Rev Dor. 2013;14(3):184-6.

2. Oliveira LM, Cruz AG. A utilização da bola suíça na promoção do parto humanizado. Rev Bras Ci Saúde. 2014;18(2):175-80.

3. Gayeski ME, Brüggemann OM. Métodos não farmacológicos para alívio da dor no trabalho de parto: uma revisăo sistemática. Texto Contexto Enferm. 2010;19(4):774-82.

4. Almeida JM, Acosta LG, Pinhal MG. Conhecimento das puérperas com relação aos métodos não farmacológicos de alívio da dor do parto. Rev Min Enferm. 2015;19(3):711-7.

5. Bavaresco GZ, Souza RS, Almeica B, Sabatino JH, Dias M. [This physiotherapist a professional to assist pregnant women]. Cienc Saude Colet. 2011;16(7):3259-66. Portuguese

6. Mendes $\mathrm{KD}$, Silveira RC, Galvão $\mathrm{CM}$. Revisão integrativa: método de pesquisa para a incorporação de evidências na saúde e na enfermagem. Texto Contexto Enferm. 2008;17(4):758-64.

7. Fontelles MJ, Simóes MG, Farias SH, Fontelles RG. Metodologia da pesquisa científica: diretrizes para a elaboraçâo de um protocolo de pesquisa. Rev Paran Med. 2010;24(1):57-64.

8. Santana LS, Gallo RB, Ferreira CH, Quintana SM, Marcolin AC. Efeito do banho de chuveiro no alívio da dor em parturientes na fase ativa do trabalho de parto. Rev Dor. 2013;14(2):111-3.

9. Pereira MC, Ribeiro L. Stresse, catecolaminas e risco cardiovascular. Arq Med. 2012;26(6):245-53

10. Benfield RD, Hortobágyi T, Tanner CJ, Swanson M, Heitkemper MM, Newton ER. The effects of hydrotherapy on anxiety, pain, neuroendocrine responses, and contraction dynamics during labor. Biol Res Nurs. 2010;12(1):28-36.

11. Reis TR, Zamberlan C, Quadros JS, Grasel JT, Moro AS. Enfermagem obstétrica: contribuiçốes às metas dos Objetivos de Desenvolvimento do Milênio. Rev Gaúcha Enferm. 2015;36(esp):94-101.

12. Gallo RB, Santana LS, Marcolin AC, Ferreira CH, Duarte G, Quintana SM. Recursos não-farmacológicos no trabalho de parto: protocolo assistencial. FEMINA. 2011;39(1):41-8.

13. Lee SL, Liu CY, Lu YY, Gau ML. Efficacy of warm showers on labor pain and birth experiences during the first labor stage. J Obstet Gynecol Neonatal Nurs. 2013;42(1):19-28.

14. Silva LM, Oliveira SM, Silva FM, Alvarenga MB. Uso da bola suíça no trabalho de parto. Acta Paul Enferm. 2011;24(5):656-62.

15. Pereira AL, Nagipe SF, Lima GP, Nascimento SD, Gouveia MS. Cuidados e resultados da assistência na sala de relaxamento de uma maternidade pública, Rio de Janeiro, Brasil. Texto Contexto Enferm. 2012;21(03):566-73.

16. Lobo SF, de Oliveira SM, Schneck CA, da Silva FM, Bonadio IC, Riesco ML. [Maternal and perinatal outocomes of na alongside hospital birth center in the city of São Paulo, Brazil]. Rev Esc Enferm USP. 2010;44(3):812-8. Portuguese.

17. Gallo RB, Santana LS, Marcolin AC, Quintana SM. A bola suiça no alívio da dor de primigestas na fase ativa do trabalho de parto. Rev Dor. 2014;15(4):253-5.

18. Araujo LM, Silva JM, Bastos WT, Ventura PL. Diminuiçáo da dor em mulheres com dismenorreia primária, tratadas pelo método Pilates. Rev Dor. 2012;13(2):119-23.

19. Taavoni S, Abdolahian S, Haghani H, Neysani L. Effect of birth ball usage on pain in the active phase of labor: a randomized controlled trial. J Midwifery Womens Health. 2011;56(2):137-40.

20. Barbieri M, Henrique AJ, Chors FM, Maia NL, Gabrielloni MC. Banho quente de aspersão, exercícios perineais com bola suíça e dor no trabalho de parto. Acta Paul Enferm. 2013;26(5):478-84

21. Henrique AJ, Gabrielloni MC, Cavalcanti AC, Melo PS, Barbieri M. Hidroterapia e bola suíça no trabalho de parto: ensaio clínico randomizado. Acta Paul Enferm. 2016;29(6):686-92. 